\title{
11
}

\section{Chinese public administration developments and prospects: An Australian (and Hong Kong) perspective}

\author{
Andrew Podger and Hon Chan ${ }^{1}$
}

\section{Introduction}

John Wanna has undertaken a number of comparative studies in his career, particularly on budget management (Wanna, Jensen and de Vries 2003, 2010; Wanna, Lindquist and de Vries 2015) and on 'Westminster' systems of government (Patapan, Wanna and Weller 2005; Rhodes, Wanna and Weller 2009). The budget management studies focus mainly on selected Organisation for Economic Cooperation and Development (OECD) countries though at least one includes China, and the 'Westminster' studies focus on former British dominions (and the UK).

Over the last decade and a half, Wanna has also become increasingly interested in China: the mainland People's Republic of China, the PRC's special zones of Hong Kong and Macau, and Taiwan. The main (but not sole) forum for this interest has been the annual workshops since 2011 of the Greater China Australia Dialogue on Public Administration, of which

1 This work was supported by the Ministry of Education of the Republic of Korea and the National Research Foundation of Korea (NRF-2017S1A3A2067636). 
he and the authors of this paper are principals (along with professors Jun Ma, Tsai-tsu Su and Meili Niu). A body of work arising from these workshops and the network of scholars Wanna helped to develop was published in the Australian Journal of Public Administration (AJPA) while he was the editor, and in ANU Press's Australia and New Zealand School of Government (ANZSOG) series of books, which Wanna has been responsible for as ANZSOG's research director. Wanna has also supervised $\mathrm{PhD}$ candidates from across Asia, and been involved in teaching and training Asian government officials, particularly in Taiwan.

There is an art in addressing the challenges of comparative research and teaching public administration and financial management for people working in very different institutional arrangements and with very different cultures and histories. Even in his 'Westminster' work, where there might seem considerable commonality of concepts derived from shared history, Wanna's work highlights just how far countries' systems have diverged, the UK itself evolving its system so significantly as to raise questions as to whether it still models some of the attributes most often associated with the term 'Westminster' (e.g. the role of cabinet). The British settlement dominions (Australia, Canada and New Zealand) have also diverged considerably, while the other former British colonies have more radically adapted 'Westminster' traditions in light of their own indigenous cultures and histories.

The art in comparative research is to identify theoretical concepts and/or challenges that are sufficiently relevant across the countries being compared, while also sufficiently specific, to allow meaningful comparisons to be made of each country's systems and practices. It also requires great care in describing each country's arrangements: as Rudolph Klein emphasised about cross-border learning, it is essential to 'learn about' before 'learning from' (Klein 2009).

Examining public administration in the PRC (referred to as 'China' below) from an Australian perspective is particularly problematic given the scale of the differences, not only in our respective political institutional arrangements but in our cultures, histories, geography, population size and wealth. 


\section{China and Australia}

As Podger and Yan highlight, the contexts in which public administration operates in China and Australia are fundamentally different (Podger and Yan 2013). Perhaps the only contextual similarity is their geographic size, both being among the six largest countries in the world, but even in terms of geography it is important to note that China is full of mountains and rivers and has multiple borders while Australia is flat and mostly dry and is an island continent with no land borders. While Australia's Indigenous history is ancient, the dominant European settlement is relatively recent and many people still debate Australia's identity; China has an ancient history of which it is proud and there is virtually no debate about its identity. Australia's culture today is mostly of European origin while China's is mostly of Han origin; Australia's population is remarkably homogeneous across its states and territories despite being increasingly multicultural, while China is quite heterogeneous with multiple languages and dialects and widely differing incomes and wealth across and within its provinces; Australia is mainly Christian-secular while China is officially non-religious but with strong influences from Confucianism, Buddhism and Taoism; most importantly, Australia's population has just surpassed 25 million, while China's is approaching 1,400 million. Australia is among the more wealthy countries in the world while China, despite its rapid economic growth, has average income per capita around one-quarter of Australia’s (on a purchasing power parity basis).

These and other contextual features impact public administration in the two countries in many ways. One of the significant impacts is the different emphases on individual and collective rights, Australia giving priority to individual rights and the rule of law, derived from its Christian and Anglo-Saxon heritage, while China (like many Asian countries) gives priority to harmony, filial piety and personal relationships and obligations (and the rule of morality), derived from Confucian, Buddhist and Taoist philosophies.

China of course is also a country in transition, from a command economy with an inward focus to a more market-based, globalised economy, its public administration also undergoing transformation as it adjusts to the requirements of a more open market economy. Its public administration arrangements are therefore not as easy to describe as Australia's, being more of a 'moving target'; Australia has a more mature framework, with 
clearer understanding of the respective roles of the market, government and civil society, and firmly embedded institutional structures. It is easier to describe what China has been moving away from than to describe how it operates today or where it might be heading in the future.

It is also difficult to identify concepts that have sufficiently common meanings to allow valid comparisons to be made of practice in the two countries. One of the authors, Podger, recalls discussions at various seminars as he and Yan presented drafts of their 2013 paper, a key concern expressed by some Chinese scholars being the danger of trying 'to fit (Chinese) round poles into (Western) square holes'. The criticism led to an important shift in the paper's approach and title, from suggesting some convergence in public administration to focusing on 'different worlds but similar challenges' (a shift suggested by Wanna and this paper's co-author, Chan). This paper also uses 'common challenges' as a useful means for comparing public administration practice.

Yet it is important also to recognise two contrasting truths about China's transition. Firstly, that its shift to a more market-based economy has led to a series of political reforms that resonate to some degree with Western experience and have delivered considerable personal freedoms as well as enhanced standards of living. There is more transparency in government, if not the formal approaches to accountability that apply in Western democracies; the social responsibilities of government are clearer; and a better informed and mobile population is able to place more pressure on government. Secondly, however, despite much conventional wisdom, there is no basis to assume that economic growth through a more marketoriented approach will necessarily cause a shift from China's one-party state authoritarianism to a Western-style, multi-party democracy.

This paper explores key aspects of China's shifting approach to public administration, drawing in part on the Dialogue workshops held since 2011 and research by the Dialogue's network of scholars. Recognising the dangers outlined above, it includes some comparisons with Australia's systems and practices, focusing on the following key issues:

- China's party system and approach towards accountability

- China's bureaucratic machinery and approach towards merit and performance management

- China's intergovernmental arrangements and approach towards subsidiarity and responsiveness. 
We conclude with some discussion about the challenges and prospects for China under President Xi Jinping.

\section{China's party system and accountability}

Article 36 of the 2018 amended Constitution of the People's Republic of China for the first time has written the phrases 'Communist Party of China (CCP)' - and its 'leadership' - into the main body of the Constitution. In the previous version of the Constitution, the party is only mentioned in the Preamble. While people in China would not say that the Preamble has no legal force, the reference to the party now in the body of the Constitution confirms the indisputable reality of the party's leadership in China. Article 36 now reads: 'The socialist system is the basic system of the People's Republic of China. The defining feature of socialism with Chinese characteristics is the leadership of the Communist Party of China'. Like the 2006 Civil Service Law, the Constitution gives the principle of party control of cadres (cadres and civil servants are the same body under the 2006 Civil Service Law) the requisite state and legal mandate, which has turned the CCP into a political institution that has become the source of both civil service empowerment and control. Some will subscribe to the view that China is expanding its political control to ensure greater leverage over the bureaucracy. In that regard, China has seemingly displayed a tendency partly in line with the global trend, including in Australia.

As a one-party state, China's institutions reflect that the party, together with the people's congresses, the people's political consultative conferences and the procuratorial organisations, constitute the principal and indispensable parts of an integrated political system. The widespread references to the party's leadership and the status and usefulness of its organisation in many laws, including the 2006 Civil Service Law and now the amended 2018 Constitution, may simply reflect a natural outcome to better fit the legal description with facts. They acknowledge and underscore the leading role of the party and its organisational divisions at various levels in cadre personnel management (Chan 2007, 391).

Through amending the Constitution, the guiding thought behind the Chinese leadership is to assert that integration between politics and administration is a unique feature (expressed by the term 'Chinese characteristics'), which contradicts some long-held assumptions with 
regard to the civil service and its relationship with politics in Western democracies (going back to the Northcote-Trevelyan Report in the UK in the 1850s and Woodrow Wilson's lecture in the US in the 1880s [Podger 2017]). Chinese leaders do not see the fusion of politics and administration as a threat to or being incompatible with a modern, permanent and competent bureaucracy. Instead, this landmark combination of politics and administration is considered a positive step towards developing a stable, adaptable, highly competent, rule-based, and legitimacy-enhancing administration (Chan 2016).

\section{The party and the civil service}

The CCP has adjusted itself to meet with the needs of its changing society in the last two decades or so. In order to establish regular adjustments in response to societal change and to guard against corruption and irregularity in its cadre personnel management system, Chinese leaders have carried out two sets of activities since 1997. The first was internal competition for posting cadres, and the second was open recruitment. Three parallel sets of regulations and laws have been introduced comprising the cadre examination syllabus and questions (2000), public announcement of employment decisions (2000), and appointment and probation arrangements (2001). All these measures were intended to build administrative capacity and to inculcate 'vitality' and 'liveliness' into the cadre personnel management system. Because politics is still taking centre stage, China has undertaken more limited administrative rationalisation. This needs to be understood within Chinas peculiar political configurations. Administrative capacity-building can be understood as efforts geared towards improving the operational efficiency of the administrative offices of party, state and other units in other sectors in society and, at the same time, retaining political authority over all sectors (Chan 2003).

Another major policy measure introduced by the CCP was to establish a party-led, merit-based talent management system in an effort to address China's talent deficit in the reform era. Since the opening up of China to the West in 1978, Chinese leaders have striven to develop a talent market that places more emphasis on merit, rather than relying solely on political loyalty. The market reform that began in the late 1970s has substantially reshaped state-market relations in China. Because the traditional nomenklatura no longer extends to the workforce in the private sector, 
the rising expansion of the private sector workforce has prompted the party to adjust its own governance mechanism. More fundamentally, the need for talents - expertise - in the rapidly developing economy of China is increasingly pressing. In response to these developments and pressures, the CCP began to look for ways to attract new talents into the cadre personnel management system. In September 1995, CCP leaders started to consider defining talents more broadly under the stance of two fundamental shifts in Chinese society: a shift from a planned economy into a socialist market economy, and a shift from extensive economic growth to intensive economic growth. The crux of the issue was a mismatch between its market-oriented economic system and its HRM (human resources management) system.

As of today, talent is categorised into two groups: cadre talent (in Chinese terminology, talent within the system, or those who are managed according to the traditional nomenklatura) and non-cadre talent (talent outside the system). With the introduction of these categories, in line with the system of 'party controlling cadres', a new system began to take shape in the early 2000s: the system of 'party management of experts'. The two systems differ in terms of the role of the party's organisation departments and the ways in which they manage talent (Chen et al. 2015).

\section{'Social accountability'}

In any comparative study, one intriguing issue is how accountability operates and how it might be enhanced. This issue is particularly interesting in relation to China. Ma (2009 and 2012) has addressed it directly, arguing that, despite the absence of competitive elections, society itself is a powerful force for enhancing accountability in China. He referred to the impact of China's 1999 budgetary reforms, which facilitated a greater role for peoples' congresses in oversight of government financial management and introduced a degree of 'horizontal accountability' as well as internal 'bureaucratic accountability', preconditions for more 'citizen participatory budgeting' or 'social accountability' (Ma 2009). Tsai (2007) made a similar argument by drawing attention to the interactions between formal and informal institutions, social structures and state structures, and social boundaries and political boundaries in ways that improve our understanding of governmental performance and public goods provision. Both scholars make a case that, when state-society is in a crisis (e.g. rampant corruption or serious invasion of citizen rights), 
society may rise up to protect itself. In a way, the CCP understands this and the seriousness of potential social problems. It is in the interest of the CCP to support some forms of social action to ameliorate statesociety relationships. Ma's papers showed that two forms of activities, either society-led action or state-led, take place simultaneously. In that regard, 'social accountabilities' seem to have provided a channel for citizens and/or civil society (however defined in China) organisations, formerly excluded from political participation, to engage in the process of governing. Particularly noteworthy is the growing importance of nongovernment organisations (NGOs). The case of $\mathrm{Nu}$ River in Yunnan Province was described by $\mathrm{Ma}$ as a turning point in China's policymaking, in that China has begun to witness an increase in the policy influence of environmental NGOs. Citizens and NGOs have begun to impose a form of societal control over the government, and the latter has become more accountable and more responsive to citizens' needs (Ma 2012, 119-120).

This development is still emerging. The growth in the number of NGOs in China has continued exponentially since Ma's papers, and the former 'dual registration' system that required NGOs to be tied to an associated ministry has been substantially relaxed. Some NGOs are now engaged by government to deliver public services and to fill capability gaps within government (Shen and Yu 2016). There remain sensitivities about NGOs' advocacy activities, however, and, most recently, pressure has been placed on NGOs to establish CCP branches within their organisations (Shen, Yu and Zhou 2020).

\section{Party, government and the market}

Since the opening of China to the West, China-watchers often raise the question of how an authoritarian regime can sustain itself in the global market. A common assumption is that, without liberating Chinese companies from bureaucratic control, China's overall economy is likely to be constrained and less effective (Koppell 2007). On the other hand, Stent (2017) argues that this line of thought is ungrounded and that continued economic growth is only partly reliant on removing CCP involvement in commercial activities, and is mainly contingent on the performance of other aspects of China's growing economy.

Since the founding of the PRC, there has been a strong tie between politics and business. The five central nomenklatura processes (disseminated in 1955, 1980, 1984, 1990 and 1998, respectively) consistently featured 
such a tie. In 1993, Chinese leaders had differentiated its public sector into three types - state organs, social institutions and enterprises. Because the leadership groups of all state-owned enterprises (SOEs) are party members, they continue to be managed by the party body. The policy measure of retaining control of the large (enterprises) while releasing the small (enterprises), adopted since the 15th Party Congress, in fact unveiled the attempt by Chinese leaders to strike a balance between political primacy and economic flexibility (Chan 2004; Song 2018).

Chan and Rosenbloom (2010) argue that Chinese public enterprises of fundamental and strategic importance to national security and economic livelihoods have always been part of the party-controlled compounds. CCP has shown no intention to privatise them in domestic and international markets or to reduce leverage over them. In making a comparison between Chinese and American public enterprises, they note that countries all over the world have adopted different public enterprise reforms with different plans and objectives. These are pursued in each country's specific political and ideological contexts and reflect the embedded relationships between public enterprises and the wider political institutions in each country. Notwithstanding the wide variations in countries' approaches to SOEs, however, including across Western market economies, a common reform theme is to improve efficiency whether the SOEs stay in public ownership or not. This is particularly important for those SOEs involved in international trade and subject to international laws and conventions. That so far is not imminent in China.

Chinese public enterprise reform is primarily a reflection of local economic nationalism, rather than efficiency alone. What Chinese leaders are trying to do is to maximise China's position in the international economic order and become strong (but not necessarily competitive, at least in the short term), especially in terms of meeting the urgent need for resources to fuel and sustain China's economic growth, through its main strategies to date of exports and investment. In the absence of a pluralist democracy in China, the pursuit of economic growth and prosperity is seen as an effective way to maintain its legitimacy. The strong tie between politics and business is also important to the entire governance mechanism at this point in China's transition, which has historically relied upon SOE revenues and assets to fund policy objectives such as social security, free education and affordable health care and the government's economic and administrative bureaucracies, and to avoid the costs of policy-induced redundant workforces. While more efficient SOEs combined with further 
tax reform might, in time, lead to greater increases in productivity along with a new, more sustainable revenue base, the transaction costs and transitional risks would be significant. China's rapid economic growth does not necessarily at this stage require making China's SOEs fully competitive in global markets and, unlike in the US, there is no political opposition to extensive government involvement in the economy. In China, many 'backbone' and 'key' public enterprises, which are considered important to the lifeline of the Chinese economy, are likely to remain under strict nomenklatura control.

On the flip side of the policy of CCP control of large enterprises, there is a need to clarify the policy of releasing small enterprises. It is difficult to spell out this policy, as the general idea is not to leave all small SOEs unattended. The CCP does not want to define strictly what constitutes a large or a small SOE. A backbone or key SOE that is not important to the central government could be a backbone or key enterprise essential to a local government. The CCP wants to strategise its resources to enable backbone or key enterprises to corporatise and be publicly listed both in domestic and global markets. The orientation of the policy of releasing the small enterprises hence could be understood as measures to enable enterprises to meet their challenges on their terms under the auspices of the respective party body. The current policy of grasping the large while releasing the small enterprises is not based on an intention to liberate Chinese enterprises from party-state bureaucratic control.

\section{China's bureaucratic machinery}

China's continued blurring of politics and administration through the overriding role of the CCP discussed above is also reflected in its approaches to personnel management in the public sector, its concept of 'merit' and its performance management system. This is notwithstanding efforts made over the last four decades to examine the challenges and problems of the cadre personnel management system in China. The promulgation of the 1993 Provisional Regulations of Civil Servants and the 2016 Civil Service Law clearly manifests different approaches taken by Chinese leaders in striking a balance between politics and administration. Core to this endeavour is the question of how far measures might be taken to reduce the direct power and authority of the CCP, such that a state civil service can function fully and effectively. 
A central issue here is the future of the rank-in-person approach in the cadre personnel management system, adopted since the founding of the nation. The rank-in-person approach, also known as the rank classification system, is a system in which every cadre is assigned a rank (instead of a particular job) and attached to a pertinent party committee. This contrasts with the rank-in-job approach, also known as the post-classification system, in which HRM is conceived as a set of jobs while a prospective employee is treated as a set of skills, knowledge and abilities that may or may not fit a particular job. Instead, a rank-in-person approach conceives HRM as a collection of people. Under the system, rank directly determines a cadre's status, fringe benefits and other monetary and political entitlements. This approach appears to support a management method that associates one's political orientation, attachment, affiliation and other related attributes to a job. A rank-in-person approach is designed chiefly to manage people but not to manage a job. When a cadre has achieved a certain rank, s/he will be locked into and controlled by respective nomenklatura. This approach clearly integrates politics and administration in enshrining the importance of political and other related attributes in personnel management.

It cannot be denied that this rank-in-person approach has become the target of criticisms. But one needs to put the background in perspective. Chinese leaders do not contemplate a Weberian type of bureaucracy. Politics, instead of administrative rationality, always takes command in China. It seems that this approach is presently able to build strong cohesion of leadership groups at each level of administration. In that light, the approach remains instrumental to any attempt to theorise how accountability is being shaped in China (Chan and Su 2009).

In today's Chinese bureaucracy, cadres are divided into two types - ordinary and leading cadres. Respective civil service divisions manage respective ordinary cadres and the respective organisation departments manage respective leading cadres. In this way, the cadre personnel management system for leading cadres is theoretically tasked with the accomplishment of political accountability. Cadre personnel management for ordinary cadres is targeted more at the fulfillment of organisational and program objectives, or 'social accountability'. One caveat that must be made here is that in every level of administration and in every agency, 'leading cadre' is a relative term. An ordinary cadre in a central ministry (such as bureaulevel official) may be a leading cadre in a lower-level administration. At a grassroots organisation level of administration (such as village or street unit), an office-level official is a leading cadre, though an office-level official is by default, and status, a non-leading cadre. 


\section{Performance management and the concept of 'merit'}

An intriguing issue may be raised: is it possible to embrace a merit principle in personnel management in China given the blurring of politics and administration? This was a key focus of the Dialogue's 2013 workshop (Podger and Chan 2015) where it was noted that the use of examinations to enter the civil service goes back far longer in China than in the West. In recent decades, China has drawn upon and adapted new public management's emphasis on performance management to refine its cadre personnel management system. The system now sets a range of performance items, targets and indicators for officials and organisations at different levels of administration and uses all these for selection, appointment and promotion purposes. Many are 'mission-based' including economic targets (e.g. the total amount of industrial output, per capita annual net income of peasants) and public service targets (e.g. the percentage of rural residents vaccinated against infectious diseases). The system also sets a range of 'non-missionbased' targets, some of which would be regarded as 'political' in Australia or elsewhere. Three types of such targets are in place: (1) anti-corruption targets (e.g. ensuring that expenditures on items like meals and entertainment are less than the amount spent in the previous year), (2) social solidarity targets (e.g. implementing family planning policies, limiting the number of mass petitions to the central government), and (3) explicit political targets (e.g. conducting ideological indoctrination through regular study sessions). While sometimes it is very difficult to differentiate mission- and nonmission-based targets, the proliferation of different types of performance items, targets and indicators in China provides evidence of continuing to embrace a merit principle in personnel management in China. It is nonetheless a very different concept of merit to that used, for example, for the Australian Public Service. There, 'political' factors have no direct bearing (though skills in communications and relationship management may well be relevant) and a range of administrative skills and capabilities as well as proven performance is used to identify the best candidate for a position.

The focus on rank-in-person rather than rank-in-job, and the emphasis on individual-based performance within the personnel management system, has affected China's adoption of performance management across government. While an increasing proportion of the targets, whether mission-based or non-mission-based, relate to economic or social or environmental outcomes, they have tended to date to be government-wide rather than organisation- or program-specific. Progress on organisational 
and program performance has been slow, though examples exist (e.g. Niu 2018; Ye and Ni 2016). Nonetheless, the National Development and Reform Commission has been promoting more systematic performance monitoring and evaluation and, as discussed below, China has been at the forefront of experimentation and evaluation to inform national policy development.

As in many OECD countries (including Australia) and some East Asian countries, China is developing sets of quantified targets with open reporting on achievements across a range of economic, social and environmental fields that offer increased capacity for social accountability, and an increased oversight role for people's congresses. With respect to work safety, for example, Chinese officials have promulgated annual performance indicators level by level down the bureaucracy in work safety. The establishment of fatality indicators to local governments is characterised by three features: (1) control by precise numbers, (2) control by zones and (3) control by hierarchical accountability. In a way, this system requires compliance from all levels of government but at the same time gives flexibility for the goalposts to be accomplished (Chan and Gao 2012). As discussed below, such arrangements involve a mix of vertical performance contracts between levels of government and horizontal reporting and related social accountability.

\section{Intergovernmental relations}

China's population and geographic size demands a multi-level system of government, notwithstanding its authoritarian party-state approach. It has forever been such, as explained in an ancient Cantonese saying: 'Mountains are high and the Emperor is far away'.

As discussed at the Dialogue workshop held in Canberra in 2012, China adopts a unitary system with decentralised administration through five layers of government, but with only the central level having 'sovereignty', as implied in federal systems of government (see the symposium of papers in AJPA Volume 72, Issue 3, 2013). Each national ministry is replicated down each level of government with strong vertical controls, while, at each level, there are also horizontal structures to ensure coordination and responsiveness to local circumstances. Nonetheless, managing this decentralised system involves similar challenges to those faced by federations such as Australias: the degree of autonomy allowed to (or exercised by) 
different levels of government, the distribution of financial powers, both vertically and horizontally, the respective roles and responsibilities at different levels, and accountability both between levels of government and to the public. Australia's experience demonstrates that success requires more than institutional stability; it also requires adaptability, responsiveness, accountability, trust and the wellbeing of the citizens being served.

The Dialogue workshop held in Hangzhou in 2014, which focused on decentralisation, explored some of the principles that may guide judgement on when devolved or decentralised administration is likely to be most efficient and effective. The principles may be grouped under three headings: subsidiarity, differentiation and experimentation, along with local capabilities (Woods and Wanna 2014). These are interdependent, the success of subsidiarity (with local authority and local provision) being dependent upon sufficient local capabilities, and with differentiation and experimentation being reliant on a degree of autonomy and local capabilities.

China faces added challenges relating to its transition from a command economy to a market economy (with some socialist characteristics). This has required redefinition of the role of government, and consequential changes to the relationships among the different levels of government.

\section{Intergovernmental finances}

The first major fiscal reform came with the 1994 tax reforms. While replacing the complex old Soviet system, separating SOE arrangements from government revenues and repairing China's fiscal decline since the reform era began (Wong 2018a and 2018b), these reforms had an enormous impact on intergovernmental financial relations. The introduction of the new system of taxes, including a national valueadded tax, greatly increased the revenues of the national government, beyond that needed for its own expenditures, giving the centre a lot more power and allowing the national government to transfer some revenues to sub-national governments; in so doing, the national government was also able to take steps towards horizontal fiscal equity, addressing some of the variations in revenue-raising capacity among the provinces and in their development needs, and also to place conditions on some of the transfers. At the same time, market-based reforms were increasing public expenditure pressures most on local governments, as the old collectives disappeared along with the social protections they provided, and as SOEs were being commercialised. 
Table 11.1 illustrates the shifts in revenue and expenditure levels and shares between the central government and local (or sub-national) governments over the reform era.

Table 11.1. Government revenues and expenditures for selected years in the reform era

\begin{tabular}{|c|c|c|c|c|c|c|}
\hline \multirow{2}{*}{ Year } & \multicolumn{3}{|c|}{ Revenues } & \multicolumn{3}{c|}{ Expenditures } \\
\cline { 2 - 7 } & $\begin{array}{c}\text { Total } \\
\text { billion } \\
\text { RMB } \\
(\%)\end{array}$ & $\begin{array}{c}\text { Central } \\
\text { government } \\
\text { billion RMB } \\
(\%)\end{array}$ & $\begin{array}{c}\text { Local } \\
\text { government } \\
\text { billion RMB } \\
(\%)\end{array}$ & $\begin{array}{c}\text { Total } \\
\text { billion } \\
\text { RMB } \\
(\%)\end{array}$ & $\begin{array}{c}\text { Central } \\
\text { government } \\
\text { billion RMB } \\
(\%)\end{array}$ & $\begin{array}{c}\text { Local } \\
\text { government } \\
\text { billion RMB } \\
\text { (\%) }\end{array}$ \\
\hline 1978 & 113.2 & 17.6 & 95.6 & 112.2 & 53.2 & 59.0 \\
& $(100 \%)$ & $(16 \%)$ & $(84 \%)$ & $(100 \%)$ & $(48 \%)$ & $(52 \%)$ \\
\hline 1993 & 434.9 & 95.8 & 339.1 & 464.2 & 131.2 & 333.0 \\
& $(100 \%)$ & $(22 \%)$ & $(78 \%)$ & $(100 \%)$ & $(28 \%)$ & $(72 \%)$ \\
\hline 1995 & 624.2 & 325.7 & 298.6 & 682.4 & 199.5 & 482.8 \\
& $(100 \%)$ & $(52 \%)$ & $(48 \%)$ & $(100 \%)$ & $(29 \%)$ & $(71 \%)$ \\
\hline 2016 & $15,960.5$ & $7,236.6$ & $8,723.9$ & $18,775.5$ & $2,740.4$ & $16,035.1$ \\
& $(100 \%)$ & $(45 \%)$ & $(55 \%)$ & $(100 \%)$ & $(15 \%)$ & $(85 \%)$ \\
\hline 2018 & $18,336.0$ & $8,617.9$ & $9,718.1$ & $22,090.4$ & $3,313.6$ & $18,776.8$ \\
& $(100 \%)$ & $(47 \%)$ & $(53 \%)$ & $(100 \%)$ & $(15 \%)$ & $(85 \%)$ \\
\hline
\end{tabular}

Source: National Bureau of Statistics of China 2019.

Central government's share of expenditure has continued to trend downwards, while its share of the revenues sharply increased with the 1994 reforms (this share falling a little in more recent years).

Not readily apparent from Table 11.1 is that the transfers to sub-national governments have not been nearly sufficient to allow them to meet their expenditure requirements without resort to (hidden) debts and unsustainable 'extra-budgetary revenues' particularly from land sales. The debts and implicit liabilities have remained a serious concern for future sustainable economic growth, even though the debts are mostly owed to domestic lenders (Ma 2012; Wong 2018a, 2018b).

A series of public financial management (PFM) reforms were pursued from the late 1990s, including changes to budget preparation and classification and Treasury management, strengthening of procurement processes and the implementation of new fiscal information systems (Wong 2009). These reforms involved the consolidation of all government revenues and expenditures and (at least in theory) the outlawing of unauthorised debt. They also strengthened the role of the National People's Congress (the legislature). 
While strong economic growth fuelled overall revenues, financial pressures on sub-national governments (some more than others) continued to increase as the party leadership from 2004 looked to spread the gains of economic growth to support a 'harmonious society', addressing mounting social issues such as social security, health insurance and access to education, and growing environmental concerns. Financial responsibility for these measures has fallen mainly on local governments.

More recent PFM reforms, particularly under the 2014 Budget Law, try to address concerns about hidden debts and unsustainable extrabudgetary revenues, and to regain oversight of fiscal resources, ensure greater transparency and improve accountability. The Law also addressed intergovernmental transfers, specifying principles and objectives and emphasising the need for regular appraisals (Wong 2018a). Rather than outlaw local government debt, the new Budget Law is a 'call to "open the front door, lock the back door and build walls around it" (Wong 2018a, 73), by stipulating that local governments must report on the purpose, size and mode of debt and specify the mechanisms of supervision and legal liabilities. As Wong highlights, implementation of the new round of reforms presents major challenges because local governments have become reliant on their off-budget revenue sources and may need to radically reduce investments to meet the new requirements; they also face capability deficits for implementing the new comprehensive financial reporting system.

\section{Roles and responsibilities}

Associated with these moves to clarify and make transparent governmental financial arrangements at all levels, and intergovernmental financial relationships, is the need for clarification of respective roles and responsibilities, and the degree of local government autonomy China will allow in its unitary system. There have been no moves to distinguish responsibilities in terms of different policy functions, but provinces and lower levels of government have varying degrees of freedom in implementing the policies set by the national government.

Those policies also allow considerable differentiation reflecting differences in provincial economic development and financial capacity. From the beginning of the reform era, the national government has also actively promoted experimentation and piloting of reforms, allowing some provinces to move ahead of others and drawing on their experience in 
setting and refining subsequent national policies. Decentralisation, and localised policy innovation, as well as the market reforms themselves, would seem to have been behind China's remarkable economic success including the lifting of so many people out of poverty.

\section{Health insurance example}

Proactive experimentation has continued as a strategy for developing and reviewing national policies, including the 'harmonious society' policies of the last decade to improve social and environmental wellbeing and spread the benefits of economic success. Developments in health insurance provide an interesting example not only of experimentation but also of the continuing constraints arising from China's past command economy and its social control arrangements. This 'path dependency' continues to shape China's approach not only to healthcare and health insurance but also to its system of decentralised government in a unitary state.

Health systems are large and complex, and their design is inevitably contextually shaped. In China's case, the design has to date been greatly influenced by its longstanding household registration system (bukou) that determines the local government to which each person is related and that in turn is responsible for providing relevant services and benefits. Under hukou, each person is tied to his or her household, which is registered with a village government (the lowest level of government). As a result of urbanisation, huge numbers of people now living in one place remain registered in another. The sending jurisdiction continues to have formal responsibility for their public services, but may be unable to provide them, while the receiving jurisdiction may lack the authority and financial resources to provide the services. This situation is made more complex because some families choose to have split arrangements, some members working in the cities and others staying in their rural villages dependent on remittances sent home, and some also are only resident in the cities while work is available.

In many respects, health care deteriorated in the first decades of economic reform as villages could no longer rely on collectives to provide services, and SOEs also cut back support for current and former employees' health and social security. Local health services began to rely on profits from pharmaceutical sales and other out-of-pocket payments by patients, reducing access to affordable care and undermining the quality of care. 
The first steps towards a national health insurance system were taken in the 1990s with the establishment of the Urban Employees Basic Medical Insurance (UEBMI) scheme, part of a new approach to social security. It was managed by provincial and city governments through the Ministry of Labour and Social Security (MLSS), later the Ministry of Human Resources and Social Security (MoHRSS), reimbursing urban employees for a substantial part of the costs of health care through approved hospitals. In practice, however, only around 25 per cent of migrant workers were ever covered by this scheme (Müller 2016).

In 2002, a New Rural Cooperative Medical System (NCRMS) was introduced, managed at the county level through the Ministry of Health, providing reimbursements for costs at county hospitals and village health centres, with funding support via intergovernmental transfers. By 2013, 99 per cent of the rural population was covered (Müller 2016) but it became apparent much earlier that there remained major gaps in real access to healthcare services by migrant workers and their families. Sending jurisdictions received higher-level government transfers for those registered with them, but no incentive to ensure access to services in their new location, while receiving jurisdictions did not receive the relevant transfers and had no financial incentive to offer support.

In 2007, a new Urban Residents Basic Medical Insurance (URBMI) scheme was introduced aimed at city residents not covered by UEBMI, who could choose to be covered by the NCRMS or the new scheme, which provided assistance for those visiting hospitals in the cities. Like UEBMI, URBMI was managed through the MLSS (now the MoHRSS). While few have taken up membership of this third scheme, a series of experiments has been undertaken to find a way to ensure more complete coverage and access to health services (Müller 2016). These include experiments involving:

- extending 'approved services' that attract NCRMS benefits, including particular hospitals in cities with numbers of migrant workers from the relevant counties

- delegating NCRMS administration to urban social insurance managers, or transferring URBMI management to the Ministry of Health, which was responsible for NCRMS

- pooling of city-level funding across NCRMS and the new URBMI

- merging of schemes across counties and even provinces. 
From 2013, all three schemes have come under the responsibility of MoHRSS, facilitating greater interoperability or mergers and more complete coverage, but problems still remain particularly for migrants who have crossed provincial boundaries. The most recent reforms are aimed to provide urban registration by 2020 for around 100 million migrant workers now registered with rural villages.

\section{Different context, similar challenges}

This example illustrates aspects of China's unique approach to intergovernmental relations when addressing challenges common to other countries with tiers of government. As in Australia, the intergovernmental financing arrangements require substantial revenue transfers to ensure capacity to fund access to affordable health care, with higher transfers to poorer provinces (and counties in China's case) to achieve a degree of horizontal equity. China's unitary system involves greater shared responsibility across tiers of government for health insurance and health services delivery, with the centre providing the policy framework and local governments the insurance management (increasingly at the provincial level) and service delivery (increasingly at the city and county levels).

The example also illustrates China's considered, almost systematic, approach to developing, testing and adapting high-level policies through differentiation and experimentation, allowing a considerable degree of local autonomy in applying and adapting central policies. There remain significant legacy issues from China's former command economy and population control arrangements that present additional challenges and will take many more years of reform to settle. And there are significant capability issues to address to ensure effective management of both financing and delivery (as Wong [2018a] has emphasised, this is true more generally about implementation of China's PFM reforms).

Other examples discussed at various Dialogue workshops, such as environmental management (Meng, Chen and Yeophantong 2020), illustrate the ongoing tensions between vertical and horizontal management in China's decentralised arrangements, and the ongoing cycles of local autonomy, experimentation and firm top-down policy direction under China's authoritarian government structure. They also highlight the challenges of local capability and the increasing importance of forms of accountability to local people including through local peoples' congresses. Informal processes (such as 'small leading groups' [Yan and 
Wu 2020]) as well as formal institutional arrangements provide means for horizontal management at local levels. And to enhance local capability, there is increasing use of external support from civil society and academia (Zhao 2018; Shen and Yu 2016) though there are also moves to increase party involvement in NGOs (Shen, Yu and Zhou 2020).

Given China's size, and its huge transition agenda constrained by legacies such as its historic rural/urban divide, its intergovernmental arrangements are understandably complex and fluid. It has some way to go to achieve institutional stability with reasonably clear financial arrangements and roles and responsibilities, but it has demonstrated that decentralisation and systematic experimentation can achieve considerable economic and social success. There remain considerable challenges regarding local capabilities, and the basic authoritarian structure of government continues to give emphasis to upwards accountability over downwards accountability to the people.

\section{Challenges and prospects in the Xi era}

China's 'socialist market economy' has always embraced a dilemma some would even suggest an oxymoron. How far towards a free market economy is China's leadership prepared to go?

The shift from a command economy has been profound and has delivered extraordinary success including the relief from poverty of hundreds of millions of people and personal freedoms unheard of in the Mao era. It has also required fundamental reform to China's political system, as the role of government has changed to take over social responsibilities previously met by collectives, party and state agencies and SOEs; to facilitate the emerging market; and to address its inevitable failures and limitations through regulation, the provision of public goods and appropriate macroeconomic settings to ensure a degree of stability. The scale of the task is difficult for outsiders to grasp, and China's leadership has been highly conscious of the risks involved. Inevitably there have been swings in the pace of reform, rapid change followed by consolidation (sometimes a reversal) followed by new waves of reform.

China is still in transition, with many agreed reforms still in the long process of implementation and with further reforms probably inevitable. Challenges of accountability, public sector capability and performance 
and intergovernmental relations remain, some of these not dissimilar to the challenges Australia continues to face. Some of the measures being taken to address them may superficially appear also to be similar to those on the agenda in Australia but, as explained here, there is no reason to expect China's reforms will lead to a political system remotely similar to Australia's or that of any other Western democracy.

Questions certainly remain about President Xi Jinping's leadership and reform intentions. He would seem to be going further than just ensuring the Constitution and legal system reflect existing reality about CCP's overall control, to be strengthening that control over the civil service, public enterprises, academia and the expanding civil society (Podger 2019; J. Garnault 2018). In addition, he has taken a stronger nationalist perspective both within China and in international relations, as signified, for example, through the Belt and Road Initiative (Cheng 2018). At the same time, he is continuing to pursue reforms aimed at enhancing capability and professionalism within the public sector, and to talk about further economic reform including increased support for free trade and the international order regulated by the World Trade Organization (Cheng 2018). He has also surrounded himself with experts with strong free market credentials (Zhang 2017).

These developments under Xi highlight the dilemma China continues to face. The strengthening of CCP control and the nationalistic approach that seems apparent are likely to constrain the further economic reforms needed for China to move on to the next stage of economic prosperity. They may also constrain both domestic pressures for improved social protection and personal freedoms and also international goodwill about China’s global leadership intentions (J. Garnault 2018; R. Garnault 2018; Paulson 2018).

But it is equally important not to misunderstand the scope for further productivity improvement and increased living standards in China within its particular framework, nor the scope for improving accountability, capability and performance notwithstanding firm CCP control. The dilemma many outside observers see need not come to a head for a long time, and even then we should not expect that the balance of government and market and civil society that is chosen will look like any of the models we see across the West. 


\section{References}

Chan, H. S. 2003. 'The civil service under one country, two systems: The cases of Hong Kong and the People's Republic of China'. Public Administration Review 63(July/August): 405-417. doi.org/10.1111/1540-6210.00304.

Chan, H. S. 2004. 'Cadre personnel management in China: The nomenklatura system, 1990-1998'. The China Quarterly 179(September): 703-734. doi.org/ $10.1017 /$ S0305741004000554.

Chan, H. S. 2007. 'Civil service law in the People's Republic of China: A return to cadre personnel management'. Public Administration Review (May/June): 383-398. doi.org/10.1111/j.1540-6210.2007.00722.x.

Chan, H. S. 2016. 'The making of Chinese civil service law: Ideals, technicalities, and realities'. American Review of Public Administration 46(4): 379-398. doi.org/10.1177/0275074016634877.

Chan, H. S. and J. Gao. 2012. 'Death versus GDP! Decoding the fatality indicators on work safety regulation in post-Deng China'. The China Quarterly 210(June): $355-377$.

Chan, H. S. and D. H. Rosenbloom. 2010. 'Public enterprise reforms in the US and the People's Republic of China: A drift towards constitutionalization and departmentalization of enterprise management'. The Journal of Institution of Public Enterprises 33(1-2): 133.

Chan, H. S. and T.-T. Su. 2009. 'Accountability and public governance in Greater China'. Australian Journal of Public Administration 68(S1): S1-S4. doi.org/10.1111/j.1467-8500.2009.00618.x.

Chen, L., H. Chan, J. Gao and J. Yu. 2015. 'Party management of talent: Building a party-led, merit-based talent market in China'. Australian Journal of Public Administration 74(3): 298-311. doi.org/10.1111/1467-8500.12141.

Cheng, D, 2018. Trade Governance of the Belt and Road Initiative: Economic Logic, Value Choices, and Institutional Arrangement. Abingdon UK: Routledge. doi.org/10.4324/9780203701911.

Garnault, J. 2018. 'Australia's China Reset', The Monthly, August.

Garnault, R. 2018. ' 40 years of Chinese economic reform and development and the challenge of 50'. In R. Garnault, L. Song and C. Fang (eds) China's 40 Years of Reform and Development 1978-2018. Canberra: ANU Press. doi.org/ 10.22459/CYRD.07.2018.02. 
Klein, R. 2009. 'Learning from others and learning from mistakes: Reflections on health policy making'. In R. M. Theodore, R. Freeman and K. Okma (eds) Comparative Studies and the Politics of Modern Medical Care. Yale University. doi.org/10.12987/yale/9780300149838.003.0012.

Koppell, J. G. S. 2007. 'Political control for China's state-owned enterprises: Lessons from America's experience with hybrid organizations'. Governance 20(2): 255-278. doi.org/10.1111/j.1468-0491.2007.00356.x.

Ma, J. 2009. 'The dilemma of developing financial accountability without election - A Study of China's Recent Budget Reforms'. Australian Journal of Public Administration 68(1): 62-72. doi.org/10.1111/j.1467-8500.2009.00622.x.

Ma, J. 2012. 'The rise of social accountability in China'. Australian Journal of Public Administration 71(2): 111-121. doi.org/10.1111/j.1467-8500.2012. 00770.x.

Meng, F., Z. Chen and P. Yeophantong. 2020. 'Assessing the vertical management reform of China's environmental system: Progress, conditions and prospects'. In A. Podger, T.-T. Su, J. Wanna, H. S. Chan and M. Niu (eds) Designing Government Structures for Performance and Accountability: Developments in Greater China and Australia. Canberra: ANU Press. doi.org/10.22459/ DGSPA.2020.09.

Müller, A. 2016. 'Hukou and health insurance coverage for migrant workers'. Journal of Current Chinese Affairs 45(2): 53-82. doi.org/10.1177/18681026 1604500203.

National Bureau of Statistics in China. 2019. China Statistical Yearbook 2018. Beijing: People's Republic of China.

Niu, M. 2018. 'Adoption or implementation? Performance measurement in the City of Guangzhou's Department of Education'. In A. Podger, T.-T. Su, J. Wanna, H. S. Chan and M. Niu (eds) Value for Money: Budget and Financial Management Reform in the People's Republic of China, Taiwan and Australia. Canberra: ANU Press. doi.org/10.22459/vm.01.2018.07.

Patapan, H., J. Wanna and P. Weller (eds). 2005. Westminster Legacies: Democracy and Responsible Government in Asia and the Pacific. Sydney: UNSW Press.

Paulson, H. M. 2018. 'United States and China at the crossroads'. Address to the Bloomberg New Economy Forum in Singapore, 7 November. Paulson Institute. Available at: www.paulsoninstitute.org/news/2018/11/06/statement-by-henrym-paulson-jr-on-the-united-states-and-china-at-a-crossroads/. 
Podger, A. 2017. 'Revisiting the relationship between politics and administration'. Wuban University Journal of Social Science 3(May). (Chinese translation of paper presented to CPAS/ASPA Conference on Modern National Governance at Wuhan University in October 2016).

Podger, A. 2019. 'Engaging with China and the US: An increasingly complex challenge, including for public administration scholars and practitioners'. Public Administration Review 79(2): 277-280. doi.org/10.1111/puar.13013.

Podger, A. and H. S. Chan. 2015. "The concept of "merit" in Australia, China and Taiwan'. Australian Journal of Public Administration 74(3): 257-269. doi.org/ $10.1111 / 1467-8500.12148$.

Podger, A. and B. Yan. 2013. 'Public administration in China and Australia: Different worlds but similar challenges'. Australian Journal of Public Administration 72(3): 201-219. doi.org/10.1111/1467-8500.12023.

Rhodes, R. A. W., J. Wanna and P. Weller. 2009. Comparing Westminster. Oxford: Oxford University Press. doi.org/10.1093/acprof:oso/9780199563494.001. 0001 .

Shen, Y. and J. Yu. 2016. 'Local government and NGOs in China: Performancebased collaboration'. China: An International Journal 15(2): 177-191.

Shen, Y., J. Yu and J. Zhou. 2020. 'The Administration's retreat and the Party's advance in the new era of Xi Jinping: The Politics of the ruling party, the government, and associations in China'. Journal of Chinese Political Science 25: 71-88. doi.org/10.1007/s11366-019-09648-5.

Song, L. 2018. 'State-owned enterprise reform in China: Past, present and prospects'. In R. Garnault, L. Song and C. Fang (eds) China's 40 Years of Reform and Development 1978-2019. Canberra: ANU Press. doi.org/10.22459/ CYRD.07.2018.19.

Stent, J. 2017. China's Banking Transformation: The Untold Story. Oxford: Oxford University Press. doi.org/10.1093/acprof:oso/9780190497033.001.0001.

Tsai, L. L. 2007. Accountability without Democracy. Cambridge, New York, Melbourne: Cambridge University Press.

Wanna, J., L. Jensen and J. de Vries. 2003. Controlling Public Expenditure: The Changing Roles of Central Budget Agencies - Better Guardians? Cheltenham, UK: Edward Elgar.

Wanna, J., L. Jensen and J. de Vries. 2010. The Reality of Budgetary Reform in OECD Nations: Trajectories and Consequences. Cheltenham, UK: Edward Elgar. doi.org/10.4337/9781849805636. 
Wanna, J., E. A. Lindquist and J. de Vries. 2015. The Global Financial Crisis and its Budget Impacts in OECD Nations: Fiscal Responses and Future Challenges. Cheltenham, UK: Edward Elgar. doi.org/10.4337/9781784718961.

Wong, C. 2009. 'Rebuilding government for the 21st century: Can China incrementally reform the public sector?' China Economic Quarterly 14(2): 22-27. doi.org/10.1017/S0305741009990567.

Wong, C. 2018a. 'Budget reform in China: Progress and prospects in the Xi Jinping era'. In A. Podger, T.-T. Su, J. Wanna, H. S. Chan and M. Niu (eds) Value for Money: Budget and Financial Management Reform in the People's Republic of China, Taiwan and Australia. Canberra: ANU Press. doi.org/10.22459/ VM.01.2018.04.

Wong, C. 2018b. 'An update on fiscal reform'. In R. Garnault, L. Song and C. Fang (eds) China's 40 Years of Reform and Development 1978-2018. Canberra: ANU Press. doi.org/10.22459/CYRD.07.2018.15.

Woods, M. and J. Wanna. 2013. 'Decentralisation of Public Administration: An Introductory Overview'. Paper presented to Greater China Australia Dialogue on Public Administration, 2013 Workshop, Hangzhou. Available via www. anzsog.edu.au/preview-documents/research-output/5350-decentralisation-ofpublic-administration-an-introductory-overview/file and the 2014 workshop on Decentralisation.

Yan, B. and J. Wu. 2020. 'Meetings matter: An exploratory case study on informal accountability and policy implementation in mainland China'. In A. Podger, T.-T. Su, J. Wanna, H. S. Chan and M. Niu (eds) Designing Government Structures for Performance and Accountability: Developments in Australia and Greater China. Canberra: ANU Press. doi.org/10.22459/DGSPA.2020.10.

Ye, L. and X. Ni. 2016. 'Assessing agency-level performance evaluation reform in China: Can it truly serve as a management innovation?' Chinese Public Administration Review 7(1): 7-34. doi.org/10.22140/cpar.v7i1.117.

Zhang, D. D. 2017. Understanding China's Politics, Economic Policy Makers, and Policy Making under Xi Jinping. Treasury Paper. Canberra: Australian Treasury, Commonwealth of Australia.

Zhao, Z. 2018. 'Case study of the role of third party evaluators in performancebased budgeting reform at the local government level in China'. In A. Podger, T.-T. Su, J. Wanna, H. S. Chan and M. Niu (eds) Value for Money: Budget and Financial Management Reform in the People's Republic of China, Taiwan and Australia. Canberra: ANU Press. doi.org/10.22459/VM.01.2018.14. 
This text is taken from Politics, Policy and Public Administration in Theory and Practice: Essays in Honour of Professor John Wanna, edited by Andrew Podger, Michael de Percy and Sam Vincent, published 2021 by ANU Press, The Australian National University, Canberra, Australia.

doi.org/10.22459/PPPATP.2021.11 